Pirineos, 157: 89 a 101, JACA; 2002

\title{
GROUPING PATTERNS IN A FOREST DWELLING POPULATION OF PYRENEAN CHAMOIS
}

\author{
J. Herrero ${ }^{1}$, I. Garin'², A. Garcia-Serrano ${ }^{3}$, \\ R. GARCtA-GONZALEZ \& A. ALDEZABAL ${ }^{5}$ \\ 'Ecology Department. Faculyy of Biology. Unibersity of Alcalí. E-28871 Alcalí de Henntes. \\ E-mail: egasl@arrakis.es \\ 2 Zoology and Animal Cell Dynamics Department. Unizersity of the Basque Country. P. O. Box 644 . \\ E-48080. Bilbo. E-mail: zopgani@ilg.ehu.es \\ ${ }^{3}$ Ega Wildife Consultants. Sierra de Vicort, 31. $1^{\circ}$ A. E-50003. Zaragozi \\ - Pyrenean Institute for Ecology, CSIC. P. O. Box 64. E-22700. Jaca. E-mail: rgarcingQipecsic. es \\ "Ecology and Plani Ecology Department. Lnizersity of the Brisque Country. P. O. Box 644. E-48080. Bilbo. \\ E-mail: gopalrongig, ehtu.es
}

ABSTRACT.- Diumal grouping in a population of Pyrenem chomois Rupicapra p. pyrenaica tons studied by divect obserntion on the edge of their wosfermost distribution. The whole area occupied by a popidnion was surzeyed by performing monthly fued tratsects ower one year. The size of 214 groups ranged from 1 to 54 . Both size and composition were quite varitble and differed between sensons and hobinis. Groups were generally very smalt ( $45 \%$ of only one animal, median: $2 ; P_{75}=4$ ), which is characteristic of small and low density forest-duriling populations. Groups appatred to depend strongly on the amnual biological cycle, food distribution and wegetation cover. The spatial segregation between males and femoles uns only toident in the summer, when solitary males wostlyoccupied the forest and fomiles with kids Irod on open pasturelands. All the general pateerns on size and conposition of the groups occured it this population.

RÉSUMÉ-Par la woie de lobservation directe nous awons êtudié le grégarisme journaier chez une population d"isard (Rupicapra p. pyrenaical a la limite occidentale de l'aire de répartition de l'espece. La surface complete ocanpre a étés stituie par de trajets fites mentsuels durant un an. La taille des differents troupenux o varie de 1 à 54 individus. De metme, la composition etait egalement tres ontiabie of changeail d'une saison a l'autre ou d'un habitat à l'aulre. De manière gén'rale, les troupeaux etaient très petits ( $45 \%$ de setulement un animal, moyenne : $2 ; P_{75}=5$ ), cist la caracléristique des petiles populations, à basse densilié el vivant en for êt. Les groupes étaient fortement conditionnés par le cycle anntuel, in distributiont des ressout rets alinentaires et le recouvrement végétal. La ségrégation spantiale entwe males at fenelles avait lieu seulement en sté, montent où les milles solitaires occupritunt surtout la 


\begin{abstract}
forêt tandis que les femelles adec les petits prefernient les pöturages ouverts. Concernant la taille et la composition des troupeaux, touts les patrons généraux ont été mis en évidence sur cette population.

RESUMEN-Se estudió por obseroución directa el gregatismo diumo en tuth pobiación de sarrio Rupicapra p. pyrenaica en el límite occidental de distribución de la subespecie. La totaldad del area ocupada fise objeto de seguintiento a partir de recorridos fijos mensuales durante un año. El tanaño de 214 grupos fue de 1 a 54 individuos. Tamaño y composición fueron muy variables y diferian entre estrciones y hábitats. Los grupos eran generalmente muy pequerios (45\% de solomente un aninul, mediana: $2 ; P_{75}=4$ ), lo que es caracteristico de poblaciones pequeñas, de baja densidad y hibitat boscoso. Los grupos dependian fuertemente del ciclo anual, distribución del alimento y cobertura pegetal. La segregación espacial entre machos y hembris ocurría solmente en terano, cuando los macios solitarios ocupaban principalmente el bosque y las hembras con crias vivian en pastos abiertos. Todos los patrones genernles referentes a timaño y composición de los grapos, se observaron en la pobiacion.
\end{abstract}

Key-words: Rupicapra pyrenaica pyrentica, Pyrenees, group size and composition, seasonal and habitat variation, biological cycle.

\title{
1. Introduction
}

The genus Rupicapra is today considered divided into two species: $R$ pyrenaica, living naturally in the Pyrenees, Cantabrian Mountains and Abruzzo; and $R$, rupicapra, in the Alps, Tatra Mountains, Anatolia, the Caucassus and several European massifs (NASCETTI et al., 1985).

The Pyrenean chamois Rupicapra pyrenaica pyrenaica (CABRERA, 1914; NASCETTI et al., 1985), is a gregarious, lowly dimorphic, cliff-dwelling mountain ungulate living exclusively in the Pyrenees mountain chain and totalling today about 40,000 animals (HIDALGO et al., 1995).

Recently, the interest for this important primary consumer in Apernines, Alps and Pyrenees and the possibilities for its ethological study as it is easily sightable, has allowed to undertake several studies on the genus, considering different aspects of its biology (ELSNER-SCHACK, 1985; RICHARDHANSEN et al., 1992). One of the subjects that has driven more attention has been social structure or grouping (RICHARD-HANSEN, 1992; BON et al., 1992,) i. e. the spatial and temporal interaction of the different age and sex classes of a population. This is a characteristic of many ungulate species, which aggregate or disperse as a result of environmental and ethological factors, which show variable group size and composition in response to environmental and ethological factors.

The kind of group in each particular moment is due to satisfy individual requirements, the kind of aggregation being optimal under a given circum- 
stance, even if to a certain extent chance can be important. The size and composition of the groups respond to a variety of factors (GEIST, 1974), as different as habitat (ALADOS, 1985; ELSNER SCHACK, 1985); food (SCHALLER, 1977; BERDUCOU, 1974); population density; sexual behaviour; differential "sociability" of sexes and ages (RICHARD-HANSEN, 1992); antipredatory behaviour (GEIST, 1974; SCHALLER, 1977), etc. As a result, ungulates normally show a great variability in their grouping patterns, even inside the same species (RICHARD-HANSEN, 1992; MAUBLANC et al., 1987; EDGE \& OLSON, 1990). Chamois show a plastic social structure, in relation with sex, density and seasons. The research on this subject allows to understand the influence of the factors affecting group's size and composition. In spite of this great variability, the main relationship is mother-kid and can go on until the second year of the kid's life (RICHARD-HANSEN, 1992). The greater seasonal variations are shown by male sociability, which can be solitary, live in male groups (BERDUCOU \& BOUSSES, 1985) or in mixed groups (only subadult males in the case of Appenuine chamois, (LOVARI \& COSENTINO, 1986).

This flexibility makes grouping a reflection of biological and environmental factors, and allows researchers and managers to use it as as an indicator of the population status in a given environment. It is also easy and quick to use, which makes it attractive for management and long-term monitoring.

The aim of this work is to describe the diurnal social strategy of a population of Pyrenean chamois during one annual cycle, living in a predominantly forested habitat and representing the westernmost range area of the subspecies.

\section{Material and methods}

The study was conducted in Larra-Belagoa Nature Reserve, a protected area of $57400 \mathrm{ha}$, in a rugged karstic relief the southwestern Pyrenees (Region of Navarre, Spain). The altitude ranges from 1100 to $2442 \mathrm{~m}$ a. s. l., annual precipitation reaches $2000 \mathrm{~mm}$ per year, and the annual mean temperature at $1500 \mathrm{~m}$ a. s. 1 . is $7^{\circ} \mathrm{C}$. During our field work there was particularly low snow precipitation.

The Pyrenean chamois is not hunted in this area and is considered "Vulnerable" in the Navarrian Regional List of Endangered Species. Demographic population characteristics are as follows: a total count of about 110 animals with a density of $5.2 \mathrm{~km}^{-2}$ and a sex-ratio of 0.63 males per female (GARIN \& HERRERO, 1997). In its westernmost distribution limit the subspecies is limited to the Natural Reserve. Other wild ungulates present are wild boars Sus scrofa and roe deer Capreolus capreolus. Sheep, cattle and horses are present from June to October in the supraforestal pastures, above timber- 
line. A small group of less than 50 domestic goats were found there all year long. The Reserve has a low human frequentation, at least considering the Chamois range, so animals are not habituated to the human presence.

From February 1992 to January 1993 at least four monthly surveys were undertaken. The surveys were done on foot, on skis and snowshoes during the period of snow, which lasted 5.5 months, and were carried out from sunrise to mid afternoon. When heavy snow was present, the surveys did not reach the higher altitudes, but observations where made from fixed points. We assumed that the surveys were representative of available habitats and altitude range in the study area in each month of the year.

We have used SCHALLER's (1977) definition in which a group is an aggregation of individuals occupying the same patch of habitat, with sensorial contact between them, and more or less coordinated in their movements. We consider also as a group one solitary animal.

Group recording was done with the scan-sampling method (ALTMANN, 1974), using $8 \times 30$ binoculars, spotting scopes (20-60) and altimeters.

Although the survey was carried out monthly, we grouped the data into bimonthly periods to increase the statistical power of the tests due to the small monthly samples. Dividing the year into bimonthly periods yields more natural units which are easily related to the Chamois annual cycle, and have already been used by other authors for the species (ELSNER SCHACK, 1985). The two-month periods were: Early Winter (January and February), Late Winter (March and April), Births (May and June), Summer (July and August), Autumn (September and October) and Rut (November and December).

Chamois were classified by age and sex considering their morphological characteristics: adult males, adult females, yearlings and kids.

Habitat units were defined from a vegetation map (ELÓSEGUI et al., 1986). The dominant types were: Mixed Beech Fagus sylvatica and Fir Abies alba Forest (Beech and Fir); Beech and Fir with Mountain pine Pinus uncinata (Beech and Pine); Mountain pine wood (Pine); Cliffs (Rocks) and Meadows (Pasture). The mountain pine habitat is a clear forest with rocks and a dense herbaceous layer.

To describe the social structure we considered size (number of animals in the group) and composition (sex and age) of the groups, habitat used and bimonthly period of the year. Every animal was considered as a unit (PUTMAN, 1986).

We used non-parametric tests due to the non normal distribution of data. Group's size variation was tested through the median test, recommended for highly assimetrical distributions (CLUTTON BROCK et al., 1982; ELSNER SCHACK, 1985; LOVARI \& COSENTINO, 1986; FOX at al., 1992; PEREZBARBERfA \& NORES, 1994). 


\section{Results}

A total of 214 groups were recorded, totalling 837 chamois. The most frequent group was one individual (45\%). Sightings of large groups were scarce: only 4 groups were bigger than 20 animals (1.9\%). The maximum group size was 54. Median group size was 2 , and percentil $75\left(\mathrm{P}_{75}\right)$ was 4 (Figure 1).

Group size differed considering habitats (Median test: $\chi^{2}=8,58 ; \mathrm{N}=837$; $\mathrm{p}=0.035$ ) (Table 1). In the Beech and Fir forest groups were smaller than in Pasture and Rocks, which represent the open habitats. In the Pine forest group size was more homogeneous than that in Rock and Pasture. Pasture showed also the biggest aggregations.

There was a significant difference between the size of the groups in bimonthly periods (Median test: $\chi^{2} 90.2 ; \mathrm{N}=837 ; \mathrm{p}=0.009$ ). Births is the most variable season regarding group size (Table 2 ). This period shows the smaller and the larger groups.

Regarding group composition, only 142 groups were considered as the sex and age of all their animals were recorded. Of the 17 possible aggregation combinations of the four categories of sex and age, only 13 were found. We grouped them into six new ones: lonely males; all-male groups; mixed group [females with kids, males (mostly 1) and eventually yearlings]; matriarcal

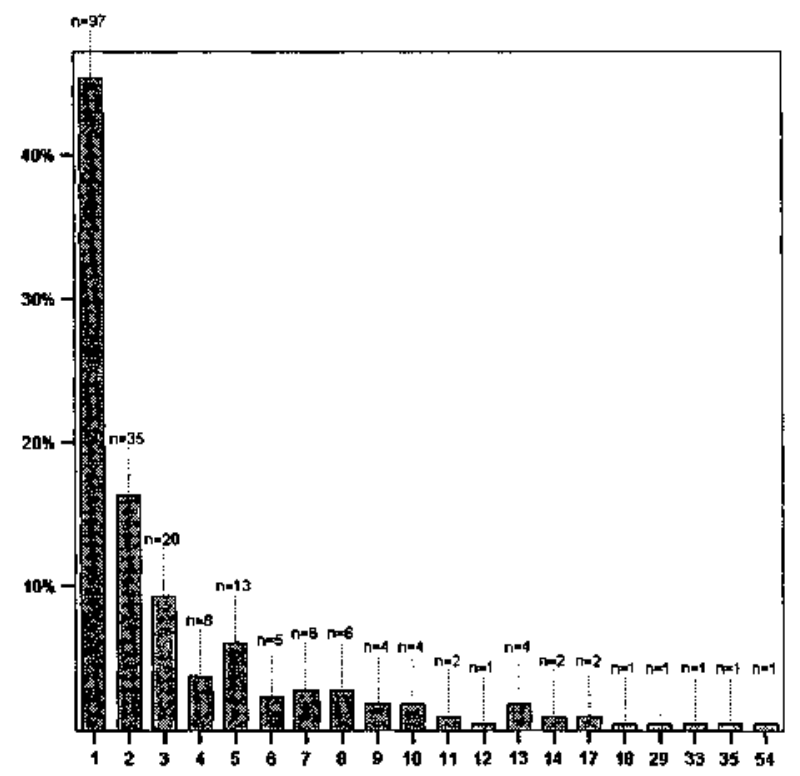

Figure 1. Grouping patterns of Pyrenean chamois in Larra-Belagoa Natural Reserve. 
group (females with kids and eventually yearlings); solitary females and yearling groups (of one or more yearlings) (Table 3).

Poptlations' group composition varied along the year. All-male groups are scarce and small, with generally only 2 males. Solitary males groups appeared all year long, specially during rut, and were minimal at the end of the winter. Lonely females are less frequent than lonely males. Lonely females appear specially during births period. Matriarcal and mixed groups total $50 \%$ of the groups, and have similar proportion of occurrence. Matriarcal groups

Table 1. Group size in selation to habitat by Pyrenean chamois in Larra-Belagoa Natural Reservation.

\begin{tabular}{|lccccccc}
\hline HABITATS & GROUPS & MEDIAN & MODE & AVERAGE & MAXIMLM & $P_{73}$ & TOTAL \\
\hline BEECH & 3 & 1 & 1 & 1,3 & 2 & 2 & 4 \\
BEECH AND PINE & 22 & 1 & 1 & 1,9 & 8 & 3 & 43 \\
PINE & 98 & 2 & 1 & 3,4 & 35 & 3 & 336 \\
PASTURE & 69 & 3 & 1 & 5,2 & 54 & 7 & 357 \\
ROCKS & 22 & 2 & 1 & 4,4 & 14 & 7 & 97 \\
TOTAL & 214 & 2 & 1 & 3.9 & 54 & 4 & 837 \\
\hline
\end{tabular}

$F_{y s}$ : percentil 75.

Table 2. Seasonal group size by Pyrenean chamois in Larra-Belagoa Naturai Reservation.

\begin{tabular}{|lccccccc|}
\hline PERIODS & GROUPS & MEDIAN & MODE & AVERAGE & MAXIMUM & $P_{75}$ & TOTAL \\
\hline EARLY WINTER & 29 & 2 & 1 & 4.14 & 18 & 5. & 120 \\
LATE WLNTER & 14 & 3 & 3 & 3.21 & 8 & 4 & 45 \\
BIRTHS & 37 & 1 & 1 & 4.54 & 54 & 1 & 168 \\
SUMMER & 42 & 2 & 1 & 3.81 & 17 & 5 & 160 \\
ALTUMN & 52 & 2.5 & 1 & 4.29 & 35 & 5 & 223 \\
RUT & 40 & 2 & 1 & 3.03 & 10 & 4 & 121 \\
TOTAL & 214 & 2 & 1 & 4 & 54 & 4 & 837 \\
\hline
\end{tabular}

$P_{75}$ percentill 75 .

Table 3. Seasonal group structure by Pyrenean chamois in Larra-Belagoa Natural Reservation.

\begin{tabular}{|lcccccccc|}
\hline GROUPS & $\begin{array}{c}\text { EARLY } \\
\text { WINTER } \\
(N=21)\end{array}$ & $\begin{array}{c}\text { LATE } \\
\text { WINTER } \\
(N=8)\end{array}$ & $\begin{array}{c}\text { BIRTHS } \\
(N=25)\end{array}$ & $\begin{array}{c}\text { SLMMER } \\
(N=27)\end{array}$ & $\begin{array}{c}\text { RUT } \\
(N=26)\end{array}$ & $\begin{array}{c}\text { ALTLMN } \\
(N=35)\end{array}$ & $\begin{array}{c}\text { TOTAL (\%) } \\
(N=142)\end{array}$ \\
\hline SOLITARY MALES & 7 & 1 & 6 & 5 & 12 & 8 & $39(28 \%)$ \\
ALL MALE & 1 & 0 & 0 & 1 & 1 & 3 & $6(4 \%)$ \\
MLXED & 5 & 5 & 4 & 2 & 7 & 11 & $34(24 \%)$ \\
MATRIARCAL & 4 & 2 & 2 & 13 & 4 & 12 & $37(26 \%)$ \\
SOLITARY FEMALES & 3 & 0 & 9 & 5 & 2 & 1 & $20(14 \%)$ \\
YEARLINGS & 1 & 0 & 4 & 1 & 0 & 0 & $6(4 \%)$ \\
TOTAL & 21 & 8 & 25 & 27 & 26 & 32 & 139 \\
\hline
\end{tabular}

N: nomber of groups. 
are more common during summer and less frequent during the rut. Mixed groups occur all year long, with a minimum during summer and a maximum at the end of winter. Mixed and matriarcal groups have an inverse, beeing mixed groups minimal and matriarcal maximal in summer. Lonely or yearling groups are also scarce and appear frequently in matriarcal or mixed groups. Yearling groups are more frequent during the births period.

\section{Discussion}

Larra-Belagoa's Pyrenean chamois social structure changes throughout the year as response to the variations in resource and food availability and reproductive cycle. Due to the small sample and low population density the most unfrequent aggregations do not happen. There are no stable groups but a general trend of each sex and age which to associate with itself (RICHARDHANSEN, 1992). There is also a great sociability of all the sex and age classes as most of the possible aggregations were found.

Open habitats favour big groups and forest small ones. This seems to be the rule for different ungulate species (GERARD et al, 1992). Forests and rough relief, favour small groups as sight contact between individuals is more difficult at great distance, while open environments help to form large ones (CLUTTON-BROCK et al., 1982).

Food supply is also an important factor. When it is concentrated produces an attraction on individuals and consequently promotes the formation of large groups (ELSNER-SHACK, 1985). If it is dispersed as happens in winter, groups should be small (BERDUCOU, 1974). Theoretically, considering what happens in other populations, food in winter is scarce and scattered and consequently groups are small (BERDUCOU, 1974), because small groups diminish food competition (MAUBLANC et al., 1987). Nevertheless, in spring and autumn, food availability is higher and groups bigger. During summer big agregations occur, because of the Chamois concentration in preferred feeding areas (GARCIA-GONZÁLEZ et al., 1985).

Antipredatory behaviour in open environments should favour large groups, as this increases individual efficiency. Even sex-ratio and productivity are demographic aspects that may determine social patterns (RICHARD-HANSEN et al., 1992) which in tum are affected by density. Finally, density is one of the most important social factors. High density promotes large groups, male groups and large matriarcal groups (BERDUCOU \& BOUSSES, 1985; GERARD et al., 1995; PEREZ-BARBERIA \& NORES, 1994), though this was argued by LOVARI \& COSENTINO (1986). This should diminish spatial segregation between sexes and ages and consequently their competition (COUTURIER, 1962). 
In Larra-Belagoa, large groups appear from May to September and the larger ones in summer (RICHARD \& MENAUT, 1989). There is a relative homogeneous small group size all year round except in the Births period, which exhibit the smaller and bigger groups (RICHARD \& CAMPAN, 1992). This is because females split before parturition (GONZALEZ \& BERDUCOU, 1985 ) and aggregate afterwards, making kindergartens with the new born kids. It is probably an antipredator behaviour in the period in which youngs are more vulnerable, where kid care is optimized, diminishing also the time spent in vigilance and increasing feeding activity (PÉPIN \& LAMERENX, 1995). We must notice that the population showed a different annual habitat use compared with the general pattern, with a less marked seasonal migration and a mainly forest use all year long (HERRERO et al, 1996) which determines the existence of smaller groups.

Mixed groups occur all year round, and not only during rut. Males show a keeping behaviour with respect to females that goes much further than a simple spatio-temporal coincidence. In the Appennines, mixed groups represent two thirds of the total groups (LOVARI \& COSENTINO, 1986). A possible justification of mixed groups abundance during all the year is low density. In the Alpine ibex Capra ibex, COUTURIER (1962) found the same situation. NIEVERGELT (1974) relates this situation with habitat in the lbex and in the Walia ibex Capra waliae. In other partial surveys carried out in the Pyrenees its absence or scarcity during summer had led to believe that this was the general pattern outside the rut (GARCIA-GONZÁLEZ, 1985; GARCÍA-GONZÁLEZ et al., 1987).

The low male sociability may be the reason for which they are more solitary. Solitary males are more common than lonely female ones and male groups are scarce. Due to the high density in the near French Pyrenees National Park, male groups are common and concentrate up to 64 (GONZALEZ \& BERDUCOU, 1985). In this case males are predominantly solitary or in all-male groups as in other populations (RICHARD \& MENAUT, 1989; GONZALEZ \& BERDUCOU, 1985) and at the same time form small groups (LOVARI \& COSENTINO, 1986). The low frequency of male groups could also be explained by low density (BERDUCOU \& BOUSSES, 1985) as in low density areas they are normally rare and small (RICHARD \& MENAUT, 1989), even though other authors disagree pointing out other posible reasons (LOVARI \& COSENTINO, 1986). LEVET \& PEPIN (1994) concluded that sociality was higher in young males in a very high density population (over 30 Pyrenean chamois $\mathrm{km}^{-2}$ ).

The male social seasonal variability is responsible for the variation in the proportion of male, mixed and matriarcal groups. The higher frequency of lonely males and all-male groups is during rut. In the Appennines the all- 
male groups appear only during rut and are normally young animals. The reason could be an exclusive participation of old males in the formation and care of harems (LOVARI \& COSENTINO, 1986). This could be the pattern in our study area, a non-hunted and 'longeve' population with old males participating in reproduction and youngs that are kept apart meeting in all-male groups. In the Cantabrian chamois Rupicapra pyrenaica paroa no all-male groups were found during rut in a hunting reservation, probably because only the supraforestal portion of the population was beeing surveyed (PÉREZ-BARBERfA \& NORES, 1995). Another posibility is that all the males were participating in the reproduction since the population was hunted probably sex-ratio should be balanced towards females.

Males show a summer spatial and social segregation (in the sense of BON et al., 1992) as in other Chamois populations (Alpine chamois, SHANK, 1985; Apennine chamois, LOVARI \& COSENTINO, 1986; Pyrenean chamois, GERARD \& RICHARD-HANSEN, 1992; GARCIA-GONZALEZ \& HIDALGO, 1989; Cantabrian chamois, PÉREZ-BARBERIA \& NORES, 1994) though there is not a marked social segregation during the rest of the year, compared with other populations. This pattern means that there is an antagonic variation in the proportion of mixed and matriarcal groups, suggesting a spatial segregation of males and females with kids when food availability is a higher. This situation can favour males (SHANK, 1985) or lactating females (ESCOS \& ALADOS, 1992), to occupy the best feeding areas. Other authors find an altitudinal segregation also in winter (LOVARI \& COSENTINO, 1986). In the particular case of Larra-Belagoa feeding areas can be considered of similar feeding quality as both the herb layer of the mountain pine forest and the open pastureland are rich and dense during summer. However the forest represents a safer habitat.

At the end of winter, male integration in female groups reaches its higher value and the male groups its lower. This minimal segregation is probably a response to food scarcity.

Yearling groups afe rare. Their frecuency is higher when yearling males are theoretically chased from mixed and matriarcal groups (GONZALEZ \& BERDUCOU, 1985).

Harem size is small because of the low density and proportional sex-ratio. Open habitats with higher visibility represents better areas to keep harems for males which can control females and other opponent males more easily as hapens in Red deer Cervus elaphus (CLUTTON-BROCK et al., 1982).

The comparison of social structure between chamois populations is difficult. Most studies have not been carried on during a whole annual cycle or have not been undertaken also in the forest, which is used mainly in the snow period. Demographic parametres are also commonly lacking. They are 
important to understand the social pattern in that particular population (GERARD \& RICHARD HANSEN, 1992): absolute abundance, total census, density, fertility and sex-ratio. This allows to know the relative proportion of the age and sex classes, that exhibit different level of sociality.

Considering a predominantly forested habitat, low density, few animals, a high sex-ratio and the rough telief; we should expect to find small groups (GONZALEZ \& BERDUCOU, 1985), small and highly frequent all-male groups and low spatial and social sex segregation (RICHARD-HANSEN, 1992). This general pattern has occurred. Some hypothesis on general patterns of social structure as the idea that small groups should appear in closed habitats and low density populations happen in Larra-Belagoa, though others do not, because female with kids, yearlings and males are frequent, and sex ratio does not lead to a high frequency of all-males groups (GERARD et al., 1995), may be because other demographic features are missing in the model.

Finally, the coincidence between the theoretical and the real social structure pattern, depending on the environment and demographic parametres mean that grouping can be an important diagnosis of the social and population status. Its aplicatipon in census and long time monitoring could be very useful.

Acknowledgments. We are greateful to D. Saavedra and all the others who helped in the field work. This paper is part of a research granted by the Regional Government of Navarre on Pyrenean chamois biology.

\section{References}

ALADOS, C. (1985). Group size and composition of the Spanish ibex (Capra pyrenaica Schinz) in the Sierras of Cazorla and Segura. In LOVARI, S. (Ed.). The biology and management of mountain ungulates: 134-147. Croom Helm, London.

ALTMANN, J. (1974). Observational study of behaviour: sampling methods. Behaviour, 49: 227-267.

BERDUCOU, C. (1974). Contribution à l'etude d'un problème éco-phisiologique pyrénéent: l'alimentation hivernale de l'isard. Ph. D. thesis, University of Toutouse, Toulouse.

BERDUCOU, C. \& BOUSSES, P. (1985). Social grouping of a dense population of chamois in the Western Pyrenees National Park. In LOVARI, S. (Ed.).The 
GROUPING PATTERNS IN A FOREST DWELLING POPULATION OF PYRENEAN CHAMOIS

biology and management of mountain ungulates: 166-175. Croom Helm, London.

BON, R.; GONZALEZ, G.; BOSCH, M. L. \& CUGNASSE, J. M. (1992). Ram rut-involvement in a hunted population of mouflons. Acta Theriologica, 37: 63-71.

CABRERA, A. (1914). Fauna Ibérica. Mamiferos. Museo Nacional de Ciencias Naturales. 441 pp. (In Spanish).

CLUTTON-BROCK, T. H.; GUINNES, F. E. \& ALBONS, S. D. (1982). Red deer. Behavior and Ecology of Two Sexes. Univ. Press. Edinburgh, Scotland, United Kingdom.

COUTURIER, A. J. (1962). Le bouguetin des Alpes (Capra aegargus ibex ibex L.). Published by the author, Grenoble.

EDGE, W. D. \& OLSON-EDGE, S. L. (1990). Poulation characteristics and group composition of Capra aegargus in Khirtar National Park, Pakistan. J. Mammal., 71 (2): 156-160.

ELOSEGUI, J.; SANTESTEBAN, I. \& SOLE, J. (1986). El Parque Natural pirenaico en Navarra. 1. Larra-Belagoa. Gobierno de Navarra. Pamplona.

ELSNER-SCHACK, I. VON. (1985). Seasonal changes in the size of chamois groups in the Ammergauer mountains, Bavaria. In LOVARI, S. (Ed.). The Biology and Management of mountain Ungulates: 148-153. Croom Helm, London.

ESCOS J. \& ALADOS, C. L. (1992). Habitat preference of Spanish ibex and other urgulates in Sierras of Cazorla and Segura. Mammalia, 56 (3): 393406.

FOX J. L.; SINHA, 5. P. \& CHUNDAWAT, R. S. (1992). Activity patterns and habitat use of ibex in the Himalaya Mountains of India. J. Mammal. 73 (3): $527-534$.

GARCÍA-GONZALEZ, R. (1985). Preliminary data on Pyrenean chamois populations in Central Pyrenees. Munibe, 37: 5-15. (In spanish).

GARCIA-GONZALEZ, R.; HERRERO, J. \& HIDALGO, R. (1987). Estimation of several population and distributional parameters of Pyrenean chamois in Central Pyrenees. Pirineos, 125: 53-63. (In spanish).

GARCIA-GONZÁLEZ, R. \& HIDALGO, R. (1989). Census and summerautumn distribution of Pyrenean chamois in Los Valles Hunting Reservation. In: Symposium Chamois, Ljubljana (Slovenia), 1988: 225-241. CIC, Paris, France.

GARIN, I. \& HERRERO, J. (1997). Distribution, abundance and demographic parametrs of Pyrenean chamois in Navarre, Western Pyrenees. Mammalia, 61 (1). (In press).

GEIST, V. (1974). On the relationship of social evolution and ecology in ungulates. American Zoologist, 14: 205-220. 
GERARD, J. F.; LE PENDU, Y; MAUBLANC, M. L.; VINCENT, J. P.; POULLE, M. L. \& CIBIEN, C. (1995). Large group formation in European roe deer: an adaptive feature? Rev. Ecol. (Terre Vie), 50: 391-01.

GERARD, J. F. \& RICHARD-HANSEN, C. (1992). Social affinities as the basis of the social organization of a Pyrenean chamois (Rupicapra pyrenaica) population in an open mountain range. Behavioural Processes, 28: 111-122.

GONZALEZ, G. \& BERDUCOU, C. (1985). Les groupes sociaux d'isards et de mouflons, au massif du Carlit (Pyrénées orientales). Gibier Faune Sauvage, 4: $85-102$.

HERRERO, J.; GARIN, I.; GARCÍA-SERRANO, A. \& GARCIA-GONZÁLEZ, R. (1996). Habitat use in a forest Pyrenean chamois (Rupicapra pyrenaica pyrenaica) population. Forest Ecology and Management, 88: 25-29.

HIDALGO, R.; CANUT, J.; HERRERO, J. \& GARCIA-GONZÁLEZ, R. (1995). Biology, ecology and management of Pyrenean chamois in the Spanish Pyrenees. Quercus, 109: 31-36. (In Spanish with english abstract).

LEVET, M., \& PÉPIN, D. (1994). Sociabilité et domaine vital d'isards (Rupicapra pyrenaica) males au printemps à Orlu (Ariège). Gibier Faune Sauvage, Game Wildl, 11: 51-64.

LOVARI, S. \& COSENTINO, R. (1986). Seasonal habitat selection and group size of the Abruzzo chamois (Rupicapra rupicapra ornata). Bollettino di Zoologia, 53: 73-78.

MAUBLANC, M.; BIDEAU, E. \& VINCENT, J. (1987). Flexibilité de l'organisation sociale du chevreuil en function des caracteristiques de l'environnement. Rev. Ecol. (Terre Vie), 42: 109-133.

NASCETTI, G.; LOVARI, S.; LANFRANCHI, P; BERDUCOU, C; MATTIUCCI, S.; ROSSI, L. \& BULLINI, L. (1985). Revision of Rupicapra Genus III. Electrophoretic studies demonstrating species distinction of chamois populations of the Alps from those of the Apennines and Pyrenees. In LOVARI, S. (Ed.). The Biology and Management of Mountain Ungulates: 56-62. Croom Helm, London.

NIEVERGELT, B. (1974). A comparison of Rutting Behaviour and Grouping in the Ethiopian and Alpine ibex. In GEIST, V. \& WALTHER, F. (Eds.). The Behaviour of Ungulates and its Relation to Management: 324-340. IUCN.

PĖPIN, D. \& LAMERENX, F. (1995). Environnement socio-spatial d'une femelle d'isard (Rupicapra pyrenaica) avant et après mise bas. Gibier Fathe Sauvage, Game Wildl., 12: 271-288.

PÉREZ-BARBERfA, J. \& NORES, C. (1994). Seasonal variation in group size of Cantabrian chamois in relation to escape terrain and food. Acta Theriologica, 39 (3): 295-305.

PUTMAN, R. J. (1986). Grazing in temperate ecosystems: large herbivores and the Ecology of the New Forest. Croom Helm, London, United Kingdom. 
RICHARD-HANSEN, C. \& CAMPAN, R. (1992). Social environment of Isard kids, Rupicapra pyrenaica p., during their ontogeny. Z. Säugetierkunde, 57: 351-363.

RICHARD, C. \& MENAUT, P. (1989). Seasonal changes in group size and association patterns in a dense population of Isard (Rupicapra pyrenaica). Abstracts of the World Conference on Mountain Ungulates, Camerino, Italy.

RICHARD-HANSEN, C. (1992). Associations between individually marked Isards (Rupicapra pyrentaica pyrenaica): seasonal and inter-annual variations. In SPITZ, F; JANEAU, G.; GONZÁLEZ, G.; \& AULAGNIER, S. (Eds.) Ongulés/ungulates, 91: 299-304. SFEPM-IRGM, Toulouse.

RICHARD-HANSEN, C.; GONZÁLEZ, G. \& GERARD, J. (1992). Structure sociale de l'isard (Rupicapra pyrenaica) dans trois sites pyrénéens. Gibier Faune Sauvage, 9: 137-150.

SCHALLER, G. B. (Ed.) (1977). Mountain Monarchs. Wild Sheep and Goats of the Himalaya. Wildlife Behavior and Ecology Series. The University of Chicago Press, Chicago and London.

SHANK, C. C. (1985). Inter- and intra-sexual segregation of chamois (Rupicapra rupicapra) by altitude and habitat during summer. Zeitschrifte für Säugetierkunde, 50: 117-125. 